\title{
Relationship between Faults and Hydrocarbon Distribution in Tahe Oilfield Southeast Slope
}

\author{
Xu Wei-wu', a, Gu Qiu-xiang ${ }^{2, b}$, Gao Ming-xing ${ }^{3, c}$ \\ ${ }^{1}$ State Key laboratory of Continental dynamics, Department of Geology, Northwest University, \\ Xi'an, Shaanxi, P.R China \\ ${ }^{2}$ Key Laboratory of Coal Resources Exploration and Comprehensive Utilization, Ministry of Land \\ and Resources, Xi'an, Shaanxi, P.R China \\ ${ }^{3}$ Shaanxi Yanchang Petroleum (Group) Co., Ltd. Research Institute, Xi'an, Shaanxi, P.R China \\ axuweiwu2014@163.com, b24833068@qq.com, 'omx0023@163.com
}

\begin{abstract}
Keywords: Ordovician. Fault. Distribution of Oil and Gas. Reservoir types
Abstract. Fault in Tahe Oilfield southeast slope has a positive meaning for more oil and gas reservoir, it can be divided into eight groups. Three of them have significant control action for the gas-water including north-south, NNE and NEE. They have closely related with fracture and karst reservoir seam holes, karst cave reservoirs and fractured reservoirs. Mostly, they get through Ordovician bottom boundary, communicating the lower part of the oil source, and become oil and gas important channel to migration upward.
\end{abstract}

\section{Introduction}

Tahe Oilfield is important oil field for Sinopec to increase reserves and production in the western region. Since 1984, high-yield industrial oil and gas flow is obtained in Radix 2 wells in the Lower Ordovician carbonate rocks the key to oil and gas exploration in Tarim Basin. It is proven that 1 billion tons reserves in this area. Study area is located in southeast slope of Tahe oilfield. Main reservoir in this oilfield is Lower Ordovician carbonate karst fractured reservoir. Lower Ordovician carbonate fracture-cave reservoir is major oil and gas reservoir. Tectonic framework and faults are complex in this area, because of experienced more tectonic [1-5].

\section{Regional Geological Setting}

Study area is located in southeast slope of Akekule nose. Rudiment of this structure formed in the late Caledonian. In early Hercynian, it formed large nose structure by regional extrusion and uplift. It gone through five major tectonic movement: (1) the late Ordovician to Silurian Caledonian mid-motion, (2) in the late Devonian, (3) late Hercynian movement in the late Permian, (4) Triassic to early Hercynian movement in the late Cretaceous Indo-Yanshan movement, (5) Himalayan movement since the Miocene. Tectonic movement in middle Caledonian, early and late Hercynian intensively impact on faults in Ordovician $\mathrm{T}_{7}^{4}$ interface, and produce different degrees of deformation transformation.

\section{Fracture distribution of study area}

According to previous studies (Tang Liangjie, 2001;Luo Kaiping, 2005;Zhao Xikui, 2009) , many tectonic stress transform Akekule nose, such as middle Caledonian (near the north-south compressional stress) - early Hercynian (north west - south east compressive stress) - late Hercynian (near the south - north tectonic compression stress) - Indosinian (NE - SW trending squeeze the role of stress). The faults formed in different tectonic stress environment and different construction period cut each other. $\mathrm{T}_{7}{ }^{4}$ on seismic unconformity shows the parallel unconformity relationship between Yijianfang and qierbake. This parallel unconformity is formed by Caledonian tectonic movement in late 
Ordovician. Most of faults relating to $\mathrm{T}_{7}{ }^{4}$ interface are reverse fault, but unevenly distributed and small. Most of them are 10 to $50 \mathrm{~m}$.

Fracture orientation classification scheme. Different tectonic stress forms different faults styles. Faults could be divided into eight directions according to the extending station in plane.(1) faults extending azimuth at 0 to 5 (175 to 180) for the east-west fault, (2) azimuth at 5 to 30 for the NEE trending faults, (3) azimuth of 30 to 60 for the north-east trending faults, (4) azimuth 60 to 85 for the north-east trending faults, (5) azimuth at 85 to 95 for the north-south trending faults, (6) azimuth at 95 to 120 for the north-west trending faults, (7) azimuth in 120-150 NW trending faults, (8) azimuth in 150 to 175 for the North West trending faults. In this partitioning scheme, fracture richness in different directions is significantly different.

Regional faults distribution. According to the distribution and direction of faults, three faults directions are more clearly, such as the NS, NNE and NEE trending faults. Single fault extending relatively long is closely related to oil, gas and water. These faults showing obviously strip constitute a fault bands. Three directions faults including NE, NWW and EW are developed in the northeastern part of the study area, but the NW, NNW and EW trending faults which is messy distribution and short extended are less development.

\section{Distribution of faults in different directions.}

(1) NS trending faults. Now, in Tahe Oilfield southeast slope $\mathrm{T}_{7}^{4}$ Ordovician interface, NS trending faults mainly included reverse faults are well developed. Single faults is relatively long in flat, but vary greatly in size. The development and distribution of faults form a plurality of NS faults zone, which have certain directions and groups. In seismic map, some faults with characteristics of multiple activities break through deep formation, but some only through $\mathrm{T}_{7}{ }^{4}$ interface. From drilling fluid produced situation, it can be concluded that these north-south fault zone, which break through deep formation, have close relationship with oil and gas wells (Figure 1).

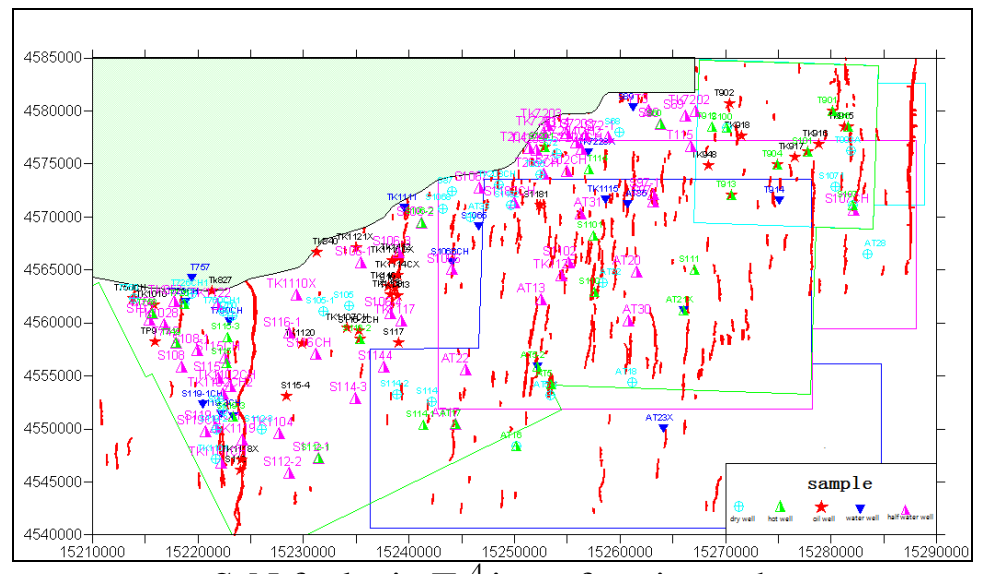

Fig. $1 \mathrm{~S}-\mathrm{N}$ faults in $\mathrm{T}_{7}^{4}$ in terface in study area 


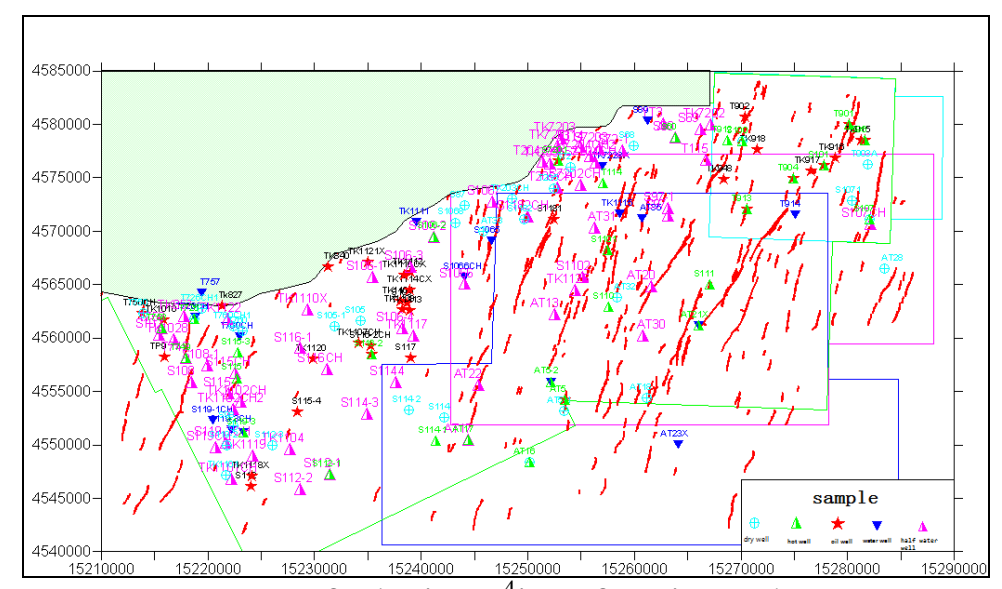

Fig. $2 \mathrm{NNE}$ faults in $\mathrm{T}_{7}{ }^{4}$ interface in study area

(2) NNE-trending faults. The NNE trending faults are most developed in $\mathrm{T}_{7}^{4}$ interface. The faults are unevenly distributed, mainly in the eastern part of the research area. In this area, the single faults mainly as reverse fault extending longer in the plane. These faults which have a clear direction and groups constitute NNE trending faults zone. Judging from the drilling fluid production, it is no obvious relation between fault directions and oil or gas wells, but the water wells in the eastern part has a certain relationship with faults direction (Figure 2).

(3) NEE-trending faults. The NEE-trending faults distribute unevenly. There are many small faults in study area. Because these faults are messy distribution and low-development, they could not constitute a significant fault. Developed faults in the east of research area constitute faults zone extending NEE trending. The reverse faults extend longer, with a certain direction and group system.Judging from production of wells in east of the research area, it can be concluded that these wells have closely relationship with these faults (Figure 3).

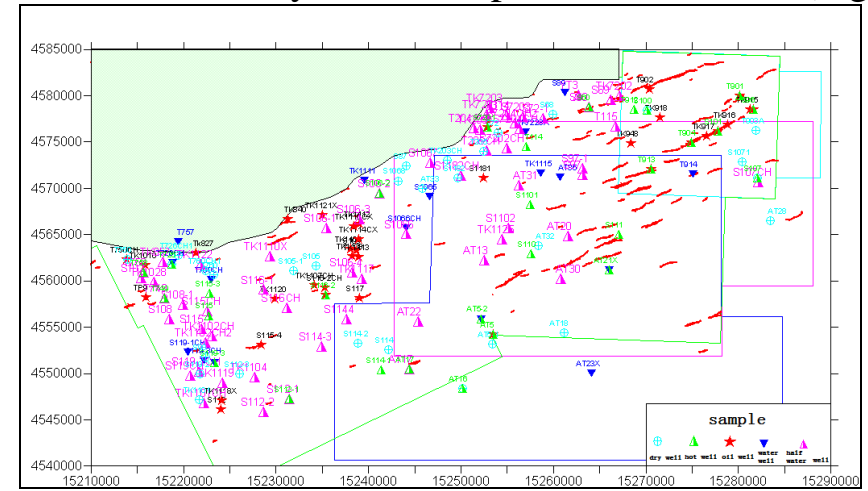

Fig. $3 \mathrm{NEE}$ faults in $\mathrm{T}_{7}{ }^{4}$ interface in study area

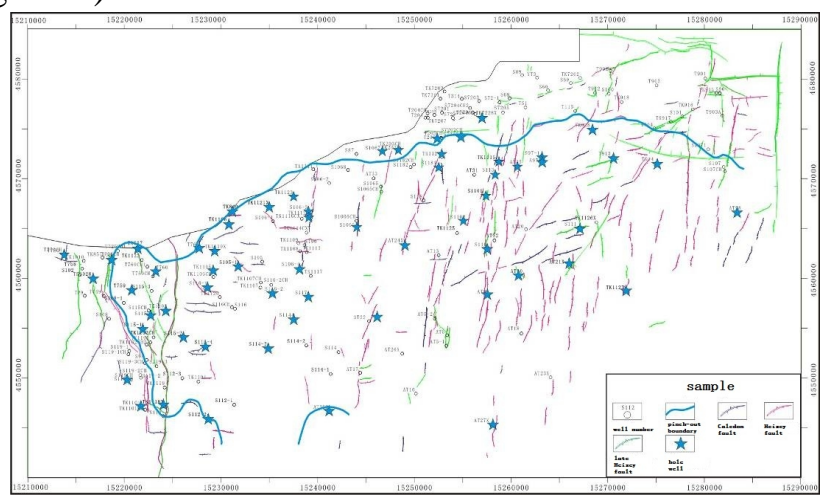

Fig. 4 relationship for karst reservoir and fracture

\section{Fracture and hydrocarbon distribution relationship}

It can be discovered that the main hydrocarbon enrichment in the research area related to multi-phase fault activities, particularly closely related to the Caledonian, early Hercynian faults activity. From faults direction, the NS, NEE, and NNE trending faults havemore closely relationship with oil and gas. From fault development state, it has closely relationship with the deep faults.

Fracture and Reservoir Type. The main Ordovician reservoir types in research area are karst reservoir seam holes, karst cave reservoir, reservoir construction and other types of fractured reservoirs. In many controlling factors of karst reservoir ,fracture is extremely important controlling factor.

Because faults and structural fracture exist in rocks, limestone and other rock formations could be permeated and corroded by water. So the faults play an important role in the development process of karst. Faulting is usually accompanied by a large number of development constructed fracture.

Results of core observation consistent with previous findings, The vast majority of medium to large cracks are showing high angle development features. Those early Hercynian tectonic fissure 
formation, due to the formation in the weathering crust environment, showing the filling or partially filling sand shale, shale, limestone breccia and crystalline calcite features.

Similarly, the development of the fracture also controls the development and distribution of the reservoir. In Figure 4, it reveals the development of the distribution of Ordovician reservoir in different fault and fracture zone.

Karst seam cavity reservoir, fractured reservoir structure, karst cave reservoirs in fault universal development, but there are differences in different parts of the fault zone.

Between the southeast faults, the main reservoir is constructed fractured reservoirs. Karst cavity reservoir seam reservoirs occupy a secondary status.

Fracture and conduit systems. Fracture has important significance for the formation of conduit systems [6-7]. Faulting cause cracks open to be a hydrocarbon migration channel. Faulting changes distribution of fracture in stratum. The more cracks, the more percolation space for oil and gas migration.

Much of faults activity occur in the research area, especially structure super imposed by north east tectonic in early Hercynian and EW structure in late Hercynian. Thesefault activity as well as related effects karst and fracture cause faults densely distributed in the research area, such as north and south, north and north-east or north NEE fault.

Many fault shows "L" type or "Y" type in profile. These fault mostly through the bottom boundary of the Ordovician, communicate the lower part of the oil source, so oil and gas indeep can migrate upward along them.

Fractured oil rate in Tahe oilfield is very high, more than half the oil sample rate reached $60 \%$, and some even reached 100 percent oil. It is said that structural fissures form early movement is effective hydrocarbon migration channel.

\section{Summary}

Tahe oilfield is located in southeast slope of Akekule. Multi-phase construction form complexity of hydrocarbon reservoir. Multi-stage fracture has a positive meaning for hydrocarbon accumulation in research area. First of all, the fracture zone can be divided into eight groups. Three groups with a significant control action for oil and gas water is named the NS direction, NNE and NEE. Three directions faults form a fault zone, can be differentiated from the plane. Secondly, fault in the plane showed the meaning of control and transformation for the reservoir, fracture and crack make a significance positive role for the of the karst reservoir, formed hole reservoir, karst cave reservoirs, tectonic fractures karst reservoir in this area. At last, faults has a positive meaning for the formation of hydrocarbon accumulation system, faults in the research area, most through the end of the Ordovician boundary, the lower part of the oil source communication has become an important channel upward migration of oil and gas.

\section{References}

[1] Charles Kerans. Karst-Controlled Reservoir Heterogeneity in Ellenburger Group Carbonates of West Texas. AAPG Bulletin, Vol.72(10)(1988),p.1160-1183.

[2] A. H. Saller,D.A.Budd, P.M.Harris. Unconformities and Porosity Development in Carbonate Strata Ideas from a Hedberg Conference. AAPG Bulletin, Vol.78(6)(1994),p.857-872.

[3] Robert G.Loucks.Paleocave Carbonate Reservoirs:Origins,Burial-DepthModification,Spatial Complexity, and Reservoir Implications. AAPG Bulletin, Vol. 83(11) (1999),p.1795-1834.

[4] MaríaVerónica Castillo and Paul Mann. Deeplyburied, Early Cretaceous paleokarstterrane, southern Maracaibo Basin, Venezuela. AAPG Bulletin , Vol. 90(4)( 2006),p.567-579. 
[5] Xu Jie, Li Tao, Cheng Guo-guang, et al. Structural Features of the Buried Hill in Lunnan Area of Tarim Basin. Acta Petrolei Sinica, vol.23,no.25(2002), p.14-18.

[6] CHEN Qiang-lu, WANG Shu-yi,QIAN Yi-xiong et al. Paleo-karst and Distribution of Oil and Gas of Lower Ordovician in Akekule Area, Tarim Basin. Acta Sedimentologica Sinica, vol.20,no.4(2002), p.633-638.

[7] Han Gehua,Qi L ixin,L i Zongjie et al. Pred iction of the Ordov ic ian fractured2vuggy carbona tereservo irs in Tahe o ilf ield. Oil and gas geology, vol.27, no.6(2006) , p.860-870. 